\title{
The effect of Chamfer to the Tensile Strength of Steel Jis S45cr Friction Welding Joints
}

\author{
lis Siti Aisyah, Muhammad Nuruddin Iqbal, Achmad Fauzan \\ Department of Mechanical Engineering \\ Engineering Faculty \\ University of Muhammadiyah Malang \\ Jl. Tlogomas No. 246, Malang 65144 \\ Phone. (0341) 464318-128 Fax. (0341) 460782 \\ Email: siti@umm.ac.id
}

\begin{abstract}
Friction welding is a joining process that utilizes the force of pressure and heat from the friction to melt the tip of the workpiece in order to be connected The research has been conducted to measure the influence of the length of one side chamfer to the characteristic of the tensile strength of steel JIS45Cr friction welding joints.

The research was conducted by experimental method with rotation speed $1800 \mathrm{rpm}$, time kept at 50 seconds, load used was $3.5 \mathrm{~kg}$, chamfer angle was $30^{\circ}$ and the length chamfer were $3 \mathrm{~mm}, 5 \mathrm{~mm}, 7 \mathrm{~mm}, 9 \mathrm{~mm}$ and 11 $\mathrm{mm}$. The tensile test conducted to find the effect of the chamfer length.

The result of the research concluded that the highest tensile test on length variant of $7 \mathrm{~mm}$, it was $97.3505 \mathrm{kN} / \mathrm{mm}^{2}$ and the lowest on $3 \mathrm{~mm}$ was $92.9868 \mathrm{kN} / \mathrm{mm}^{2}$. It is proved that the chamfer length effect to thee tensile strength of friction welding.
\end{abstract}

Keywords: Friction welding; steel JIS S45Cr; Chamfer; Tensile test.

\section{INTRODUCTION}

Friction welding is a solid-state joining process that induced through rotation in a combination between one of the rotated workpiece and the mechanical pressure. This mechanical friction will generate heat that melts both the edge of workpiece and it became a joining process [1].

In the friction welding, there are 4 changing phase such as solid phase, transition phase, steady phase, and cooling down phase. In the solid phase, the friction will appear from the two rubbing materials, the combination of this matter, rotational speed and pressure will increase the heat [6]. The important parameters on the friction welding process are friction time, rotational speed, and friction pressure [3].

Poedji Haryanto [5], have observed the friction welding on steel ST 60 by using lathe complete with loading mechanism to achieve the axial pressure. The tensile test, the hardness test, also the micrographs photo with pressure variant, the rotational speed, and the friction time are already done as well and the result is the joining process proven successfully. It is shown while having the tensile test, the specimen has broken outside the welded that indicates there is hardness increasing on the welded area. Besides, there has been a better solid process of micro structure on the welded area than outside. However, this observation is not yet discussing about the influence chamfer toward the strength of steel JIS S45Cr friction welding joints. Furthermore, it needs more observation about the influence of the length variant of angle one side chamfer to generate the tensile strength of steel JIS S45Cr friction welding joints. 


\section{Methodology}

The research method on this research is using experimental method which purposes to know the influence of one side chamfer length toward the tensile strength of steel JIS S45Cr friction welding joints.

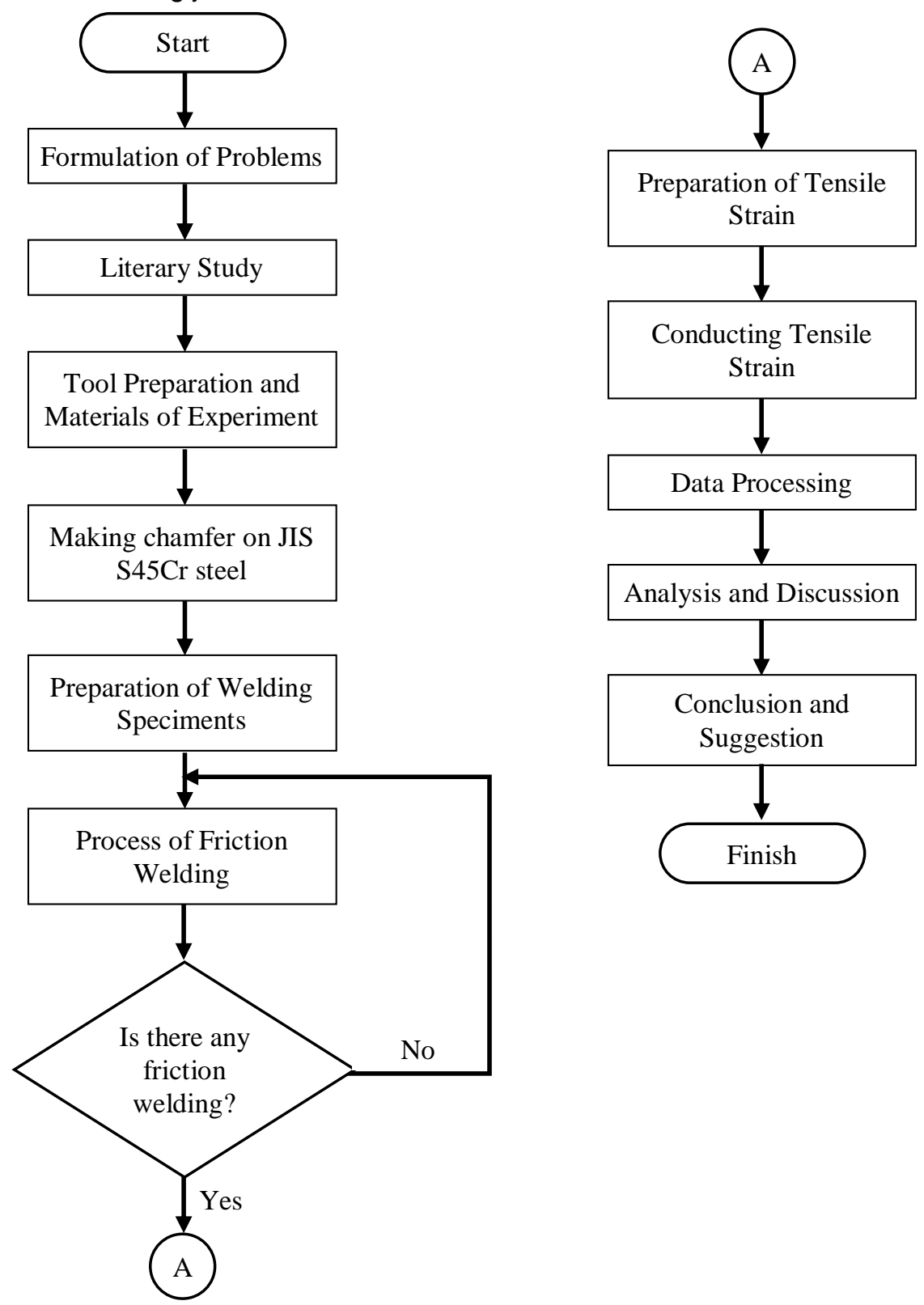

Figure 2.1 Flowchart of Research

This friction welding research is conducted in production laboratory of Machine Engineering of Muhammadiyah Malang University, and for welding joints tensile test is conducted in material testing laboratory of Mechanical Engineering of Muhammadiyah Malang University.

Before conducting the research, the writers prepare some tools such as, lathe, specimen clamp, sandpaper, saw, ruler, caliper, stopwatch, pulley, compensating rope, iron box, load $3.5 \mathrm{~kg}$, tensile test machine and one side chamfer formation on the carbon steel material JIS S45Cr that will be welded on $30^{\circ}$ and its length will be varied into $3 \mathrm{~mm}$, $5 \mathrm{~mm}, 7 \mathrm{~mm}, 9 \mathrm{~mm}, 11 \mathrm{~mm}$. 


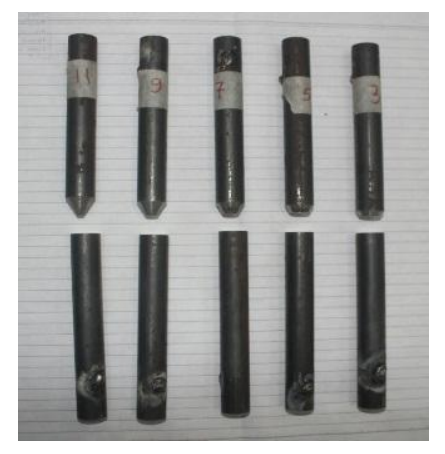

Figure 2.2 Specimen before Welding Run

Beside preparing the required tools for the research, the next step is adjusting lathe with speed $1800 \mathrm{rpm}$, time 50 seconds, load $3.5 \mathrm{~kg}$ to easier to adjust the load height in order to both surfaces can connect each other and it is able to start the friction welding process.

In case all the preparation is set already, start to press the "ON" button and the lever to operate the lathe and record all the friction welding process. The time limit for every process is 50 seconds only.

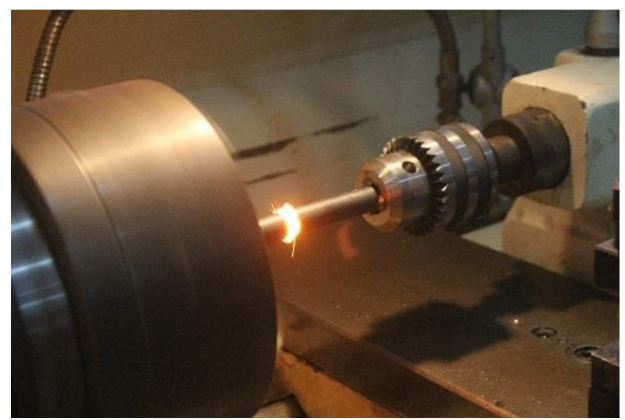

Figure 2.3 Friction Welding Process

The next step after having the friction welding is forming specimen for tensile test based on the standard ASTM E-8 by lathe. The tensile test is conducted in every welding joints specimen. It purposes to know the chamfer influence toward the characteristic of tensile strength of steel JIS S45Cr friction welding joints.

\section{Results AND Discussion}

\subsection{The Result of Friction Welding with the Length Variant of Chamfer}

The picture below is a joints form after being friction welded within 50 seconds, speed $1800 \mathrm{rpm}$ and using length variant of chamfer. Here is the length variant of chamfer:

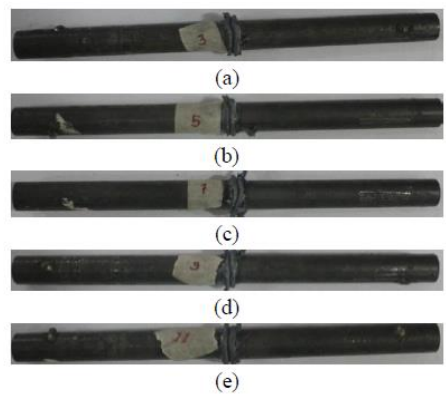

Figure 3.1 Joint of Friction Welding Process 
(a) = Chamfer length $3 \mathrm{~mm}$

(b) = Chamfer length $5 \mathrm{~mm}$

(c) = Chamfer length $7 \mathrm{~mm}$

(d) $=$ Chamfer length $9 \mathrm{~mm}$

(e) = Chamfer length $11 \mathrm{~mm}$

\subsection{The Tensile Test Result}

Based on the observation in Metal Testing Laboratory in Machine Engineering of Muhammadiyah Malang University, it finds the data as a graphic of loading tensile test for each specimen. The tensile test has been done for getting the value of joints tensile strength from each specimen that been friction welded with speed $1800 \mathrm{rpm}$, load $3.5 \mathrm{~kg}$, time 50 seconds and the length variant of chamfer as $3 \mathrm{~mm}, 5 \mathrm{~mm}, 7 \mathrm{~mm}, 9 \mathrm{~mm}$ and 11 $\mathrm{mm}$. Here is the data of the tensile test result as below:

\begin{tabular}{|c|c|c|c|c|}
\hline No. & $\begin{array}{c}\text { Angle } \\
\text { Length of } \\
\text { Chamfer } \\
(\mathrm{mm})\end{array}$ & $\begin{array}{l}\text { Chuck } \\
\text { Rotation } \\
\text { (Rpm) }\end{array}$ & Fracture Form & Description \\
\hline 1 & $3 \mathrm{~mm}$ & 1800 Rpm & & Tough Fracture \\
\hline 2 & $5 \mathrm{~mm}$ & 1800 Rpm & & Tough Fracture \\
\hline 3 & $7 \mathrm{~mm}$ & 1800 Rpm & & Tough Fracture \\
\hline 4 & $9 \mathrm{~mm}$ & 1800 Rpm & & Tough Fracture \\
\hline 5 & $11 \mathrm{~mm}$ & 1800 Rpm & & Tough Fracture \\
\hline
\end{tabular}

Figure 3.2 Fracture of Joint after Tensile Test

Note: The ductile fracture is identified by energy absorption tag along with the sufficient plastic deformation around the fracture, so the surface of fracture looks rough, fibrous, and the cross section of the object become smaller.

JEMMME | Journal of Energy, Mechanical, Material, and Manufacturing Engineering 


\subsection{The Analysis of Tensile Test Result}

Table 3.1 Data of Tensile Test

\begin{tabular}{cccccccc}
\hline No & $\begin{array}{c}\text { Speciment } \\
(\mathbf{m m})\end{array}$ & $\begin{array}{c}\text { Yield limit } \\
\left(\boldsymbol{\sigma}_{\mathrm{y}}\right)\end{array}$ & $\begin{array}{c}\text { Tensile } \\
\text { Strength } \\
\left(\boldsymbol{\sigma}_{\mathrm{u}}\right)\end{array}$ & $\begin{array}{c}\text { Fracture } \\
\text { Strain } \\
\left(\boldsymbol{\sigma}_{\mathrm{f}}\right)\end{array}$ & $\begin{array}{c}\text { Tensile Strain } \\
(\boldsymbol{\sigma})\end{array}$ & $\begin{array}{c}\text { Strain } \\
(\%)\end{array}$ & $\begin{array}{c}\text { Elasticity } \\
\text { Modulus } \\
(\mathbf{E})\end{array}$ \\
\hline 1. & 3 & $58.2634 \mathrm{kN}$ & $92.9868 \mathrm{kN}$ & $70.5582 \mathrm{kN}$ & $0.7638 \mathrm{kN} / \mathrm{mm}^{2}$ & 14.4623 & 0.0528 \\
\hline 2. & 5 & $58.5960 \mathrm{kN}$ & $95.3632 \mathrm{kN}$ & $73.9061 \mathrm{kN}$ & $0.7833 \mathrm{kN} / \mathrm{mm}^{2}$ & 13.4426 & 0.0582 \\
\hline 3. & 7 & $59.3572 \mathrm{kN}$ & $97.3505 \mathrm{kN}$ & $73.5941 \mathrm{kN}$ & $0.7997 \mathrm{kN} / \mathrm{mm}^{2}$ & 42.8351 & 0.0186 \\
\hline 4. & 9 & $57.4142 \mathrm{kN}$ & $95.4764 \mathrm{kN}$ & $72.9404 \mathrm{kN}$ & $0.7843 \mathrm{kN} / \mathrm{mm}^{2}$ & 14.473 & 0.0628 \\
\hline 5. & 11 & $58.7172 \mathrm{kN}$ & $93.8074 \mathrm{kN}$ & $71.5608 \mathrm{kN}$ & $0.7706 \mathrm{kN} / \mathrm{mm}^{2}$ & 15.5077 & 0.0496 \\
\hline
\end{tabular}

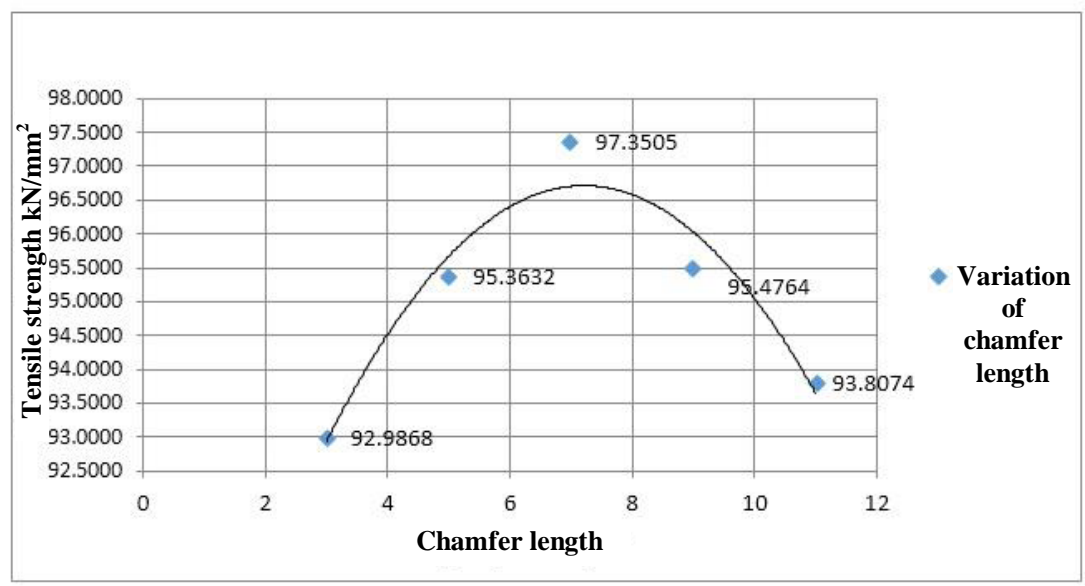

Figure 3.3 Result of Tensile Strain

The graphic above shown the value of maximum voltage from each length variant of chamfer that are $0 \mathrm{~mm}, 3 \mathrm{~mm}, 5 \mathrm{~mm}, 7 \mathrm{~mm}, 9 \mathrm{~mm}, 11 \mathrm{~mm}$ and the angle of chamfer is 30 . By this report, we are able to see the data that the highest of the value of maximum voltage is on the specimen that use the chamfer length $7 \mathrm{~mm}, 9 \mathrm{~mm}, 5 \mathrm{~mm}, 11 \mathrm{~mm}$ and the lowest is $3 \mathrm{~mm}$, and we draw a conclusion that the chamfer length is proven having an influence toward the tensile strength of friction welding joints. The lowest tensile strength value for the specimen of chamfer length $3 \mathrm{~mm}$ is $92.9868 \mathrm{kN}$, then for the specimen of chamfer length $5 \mathrm{~mm}$ increases as much as $95.3632 \mathrm{kN}$. This thing happens because the surface area that rubs each other is too wide and makes the heat from the material too high. The angle of chamfer will influence toward the friction welding joints contact area. The bigger of it makes the bigger of heat input, and it brings an effect the formed HAZ area also bigger which induces the decrease of the friction welding joints tensile strength [4].

The most ideal specimen that has an increase value of tensile strength and being the highest tensile strength value among others as much as $97.3505 \mathrm{kN}$ is the chamfer that has $7 \mathrm{~mm}$ length variant. It is caused by the function of chamfer angle is able to center the melting point while welding process, so the material that rub each other while melting process is getting faster and more optimum to bond together. The tensile strength will increase along with the smaller angle of chamfer and the porosity will decrease along with the bigger angle of chamfer [6].

However, the tensile strength for a longer specimen of chamfer length $9 \mathrm{~mm}$ tends to decrease as much as $95.4764 \mathrm{kN}$ and the chamfer length $11 \mathrm{~mm}$ reaches $93.8074 \mathrm{kN}$. It happens because of the longer chamfer itself, so the material melts too much and it makes longer cooling down process, so the generated heat spread and it affects mechanical material properties. This case leads the decreasing tensile strength value of welding joints again. The longer period for welding, makes the decreasing of welding strength due to the flash is formed much more, and it affects the cooling down process [2]. 
The performance of the friction welding on weld metal that has been tensile tested has a perfect point, where it is able to increase the joints on steel JIS S45Cr friction welding. It shows that by using chamfer on steel diameter $16 \mathrm{~mm}$, with speed $1800 \mathrm{rpm}$, load $3.5 \mathrm{~kg}$ and time 50 seconds generates the strength of the friction welding results is higher than the strength of JIS S45Cr main metal steel.

\section{Conclusion And Suggestion}

\subsection{Conclusion}

According to the friction welding performance on steel JIS S45Cr that has been done on the chamfer length $3 \mathrm{~mm}, 5 \mathrm{~mm}, 7 \mathrm{~mm}, 9 \mathrm{~mm}$ and $11 \mathrm{~mm}$, friction time 50 seconds with speed $1800 \mathrm{Rpm}$ then been tensile tested to know the tensile strength, we draw a conclusion that the order of tensile strength value from the highest are on the specimen chamfer length $7 \mathrm{~mm}, 9 \mathrm{~mm}, 5 \mathrm{~mm}, 11 \mathrm{~mm}$ and $3 \mathrm{~mm}$ is the lowest, and it is proven that the chamfer has an influence toward tensile strength of friction welding joints.

The highest tensile strength value that achieves $97.3505 \mathrm{kN} / \mathrm{mm}^{2}$ is the chamfer that has $7 \mathrm{~mm}$ length variant and the lowest is specimen of chamfer length $3 \mathrm{~mm}$ which reaches $92.9868 \mathrm{kN} / \mathrm{mm}^{2}$ from the steel tensile strength before friction welding as much as $72.3 \mathrm{kN} / \mathrm{mm}^{2}$.

The angle of chamfer is able to increase the tensile strength of welding joints along the friction welding process. However, the chamfer that is too long can decrease the tensile strength value again. It is led by the function of chamfer angle is able to center the melting point, so if the chamfer is too long, it will melt more material and affect the cooling down process. Based on the welding process, the performance of the friction welding on weld metal that has been tensile tested has a perfect point, where it is able to increase the joints on steel JIS S45Cr friction welding, so the fracture position moves into HAZ area. It shows that by using chamfer on steel diameter $16 \mathrm{~mm}$, with speed $1800 \mathrm{rpm}$, load $3.5 \mathrm{~kg}$ and time 50 seconds generates the strength of the friction welding results is higher than the strength of JIS S45Cr main metal steel.

\subsection{Suggestion}

Based on the research that has been done, it is suggested for the next researcher to have more development the friction welding. Because there is a probability if by using two sides - chamfer will give a significant impact toward the tensile strength and it is a good point to learn more and get more knowledge about friction welding.

\section{REFERENCES}

[1] Astrom, P., Näsström, M. Optimization Of Parameter In A Friction Model For Fiction Welding Simulation of Ti-6246. Materials Park, Ohio : ASM International. 2006: 849 854.

[2] Amirullah, Muhammad. Pengaruh Sudut Chamfer Satu Sisi Dan Friction Time Terhadap Kekuatan Puntir Pada Sambungan Las Gesek Al-Mg-Si. Malang: Teknik Mesin Strata 1 Universitas Brawijaya; 2014.

[3] Irawan, Y., S, Wirohardjo, M., Ma'arif, M, S. Tensile Strength of Weld Joint Produced by Spinning Friction Welding of Round Aluminum A6061 with Various Chamfer Angles. Advanced Material Research. 2012; 576: 761 - 765.

[4] Imawan, Bustanul. Pengaruh Sudut Chamfer dan kekerasan Permukaan Terhadap Kekuatan Tarik Sambungan Las Gesek Al-Mg-Si. Malang: Teknik Mesin Strata 1 Universitas Brawijaya; 2014.

[5] Haryanto, Poedji. Pengaruh Gaya Tekan, Kecepatan Putar, dan Waktu Kontak pada Pengelasan Gesek Baja ST60 Terhadap Kualitas Sambungan Las. Semarang: Politeknik Negeri Semarang; 2011.

[6] Santoso., Eko., Budi. Pengaruh Sudut Chamfer dan Gaya Tekan Akhir Terhadap Kekuatan Tarik dan Porositas Sambungan Las Gesek Pada Paduan Al-Mg-Si. 2012. 